\title{
第 31 回日本透析療法学会・D般演題
}

\section{ダイアライザー生体適合性}

座長 山上 征二（大阪市立大学）

猿渡 和久（福岡胃腸心臓センター）

透析膜と血小板機能（第 1 報）

$\begin{array}{llll}\text { 日本大学第 } 2 \text { 内科 } & \text { 前島 } & \text { 司, 岡田 一義, 久野 } & \text { 勉 } \\ & \text { 下村 } & \text { 滋, 岩淵 } & \text { 文夫, 岡 善政 } \\ & \text { 島田 } & \text { 明仁, 井上 通泰, 竹内 } & \text { 誠 } \\ & \text { 高橋 } & \text { 進, 波多野道信 }\end{array}$

(707)

透析膜の相違による透析中のリンパ球サブセットの変動の差

福岡胃腸心臓クリニック

稲永隆, 大地 信彰, 平田 克幸 猿渡 和久

九州大学第 2 内科 名西 史夫，小野山 薫，藤島 正敏

福岡赤十字病院腎センター 藤見惺

新しく開発された modified cellulose dialyzer の生体適合性評価

$\begin{array}{ll}\text { 東京女子医科大学腎臟病総合医療センター } & \text { 佐々木優里, 寺岡 慧, 高橋 満彦 } \\ & \text { 江良 和雄, 峰島三千男, 久保 和雄 } \\ & \text { 太田 和夫 }\end{array}$

血液透析中のロイコトリエンの変動について

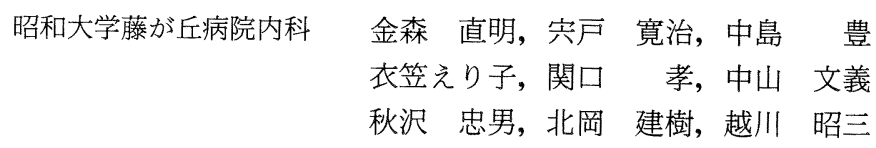

透析患者におけるエチレンオキサイド（EO）皮膚アレルギーの発現性について

$\begin{array}{llcl}\text { 千葉社会保険病院 } & \text { 桜井 } & \text { 信也, 伊藤 } & \text { 家勝, 永吉 武彦 } \\ & \text { 岩崎 } & \text { 秀明, 嶋田 俊恒 } \\ \text { 三愛記念クリニック } & \text { 鹿島 } & \text { 孝 } & \\ \text { 千葉大学第 } 2 \text { 外科 } & \text { 大島 } & \text { 郁也, 小高 通夫 }\end{array}$

血液透析患者の血中 limulus test 陽性物質について（第 2 報）

\begin{tabular}{|c|c|c|c|}
\hline 聖マリアンナ医科大学臨床検査医学 & $\begin{array}{l}\text { 青山 } \\
\text { 中村 }\end{array}$ & $\begin{array}{l}\text { 悦子, 山本 } \\
\text { 正夫 }\end{array}$ & 光祥, 野沢 \\
\hline 同腎センター & 金沢 & $\begin{array}{l}\text { 司, 小嶋 } \\
\text { 尚士 }\end{array}$ & 茂利, 大和田 \\
\hline
\end{tabular}




\section{唀析膜と血小板機能（第 1 報）}

前島司 岡田一義 久野 勉下村 滋 岩㴊 文夫 岡 善政島田 明仁井上通泰 竹内 誠高橋進波多野道信

日本大学第 2 内科

膜素材の異なった dialyzer を用い, 血小板機能の面より, その生体適合性について比較検討した。対象は安定した維持 HD 患者であり, dialyzer として HF 型を使用の cellulose -acetate (CA) 膜 10 名, cuprophan (C) 10 名, ethylene -vinyl-alcohol copolymer (EVA) 5 名である. HD 開始前, 開始後 $15,30,60,120$ 分, 終了時に動脈側より採血し, 血 小板数, 血漿 $\beta$-thromboglobulin ( $\beta$-TG), platelet factor -4 (PF-4) および血小板凝集能を経時的に測定，なお凝集能 は全血によるインピーダンス法を応用し, 惹起剤として colagen ristocetin を用いる。

$\mathrm{CA}, \mathrm{C}$ および $\mathrm{EVA}$ 膜ともに血小板数および血小板凝集能 は, $\mathrm{HD}$ 開始後一時的に減少し, 15 分ないし 30 分に減少の ピークとなる。しかしその後は漸次増加し, 終了時には前值 に比べ増加している，EVA 膜では CA, C 膜と比べその減少 は軽度であり,また回復も早い. $\beta-\mathrm{TG}$ の変化は 3 者ともに, $\mathrm{HD}$ 開始後より漸次増加し終了時にピークとなる.EVA 膜で は HD 後 60 分, 120 分, 終了時で他の 2 者に比べその上昇率 は有意に低下している．PF-4 はその抗へパリン作用のため か 3 者ともに HD 開始早期に著増し，15 分ないし 30 分で ピークとなりその後低下していく．CA および C膜では血小 板機能に明らかな違いは認められないが EVA 膜では血小板 機能に及ぼす影響は少なく，他の 2 者に比べ生体適合性の面 でよりすぐれていると推察できる。しかし膜の生体適合性の 評価の指標およびその方法は種々あり，血小板機能のみより 生体適合性の評価を下すことは早計である.

\section{透析膜の相違による透析中のリンパ球サブセットの変 動の差}

稲永 隆 大地信彰 平田克幸 猿渡 和久 名西 史夫 ${ }^{* 1}$ 小野山 薰 ${ }^{* 1}$ 藤島 正敏 ${ }^{* 1}$ 藤見 惺 ${ }^{* 2}$ 福岡胃腸心臟クリニック 九州大学第 2 内科*1 福岡赤十 字病院腎センター*2

透析膜素材の生体適合性が注目されているが，今回我々は 2 種類の透析膜を使用し HD 中のリンパ球サブセットの変 動について検討した。安定した慢性血液透析患者 8 名を対象 とした。年齢は $20 \sim 61$ 歳 (平均 $42.3 \pm 12.1$ ), 透析歴は 39〜135 力月（平均 83.5 533 .3）であった。採血は cuprophane (C) 膜使用時および PMMA 膜に変更 2 週間後の $\mathrm{HD}$ 開始直前, 開始 15 分後および 300 分後に行いリンパ球サ ブセット， $\mathrm{C}_{3 \mathrm{a}}$ 等を測定した.

好中球 (\%) は C 膜では HD 開始 15 分後に有意に低下し， 300 分後に増加したが, PMMA 膜では有意な変化はなく, リ ンパ球 $(\%)$ は開始 15 分後に C 膜で好中球の減少のため相対 的に増加し, HD 開始 300 分後には両膜とも低下していた. OKT 4 （\%）は両膜とも HD 開始 300 分後で有意な増加を認
め, 逆に OKT 8 （\%）は有意な低下を認めた。 OKT 4/OKT 8 比は HD 開始 15 分後 cuprophane 膜では変化を認めな かったが，PMMA 膜では有意に増加していた。好中球，リ ンパ球抒よびリンパ球サブセットの比率はダイアライザー (C月莫, HD 開始 15 分後) の前後で有意差はなかった。 C3a は C膜で HD 開始 15 分後に有意に増加していた。T細胞に は補体レセプターがないと考元られており HD 開始 300 分 後に生じたOKT 4 （\%）の増加とOKT 8 （\%）の減少は補体 活性化とは別の機序によるものと思われる。単に体内におけ る distribution の変化の可能性もあると思われるが，現時点 でははっきりしたメカニズムは不明である。

\section{新しく開発された modified cellulose dialyzer の生体適 合性評価}

佐々木優里 寺岡 慧 高橋 満彦 江良 和雄

峰島三千男 久保 和雄 太田 和夫

東京女子医科大学腎臟病総合医療センター

血流浄化法に使用する膜には種々あるが，新しく開発され た Enka modified cellulose 膜は生体適合性の面で優れてい るといわれている。 今回，再生セルロース，PMMA，および modified cellulose (Hemophan) を用いた dialyzer を，長 期透析療法施行中の患者に使用し, この 3 種類の膜を生体適 合性の面より比較検討したので報告する。 5 名の長期透析施 行中の患者に Hemophan を用い, 静脈側回路より継時的に 採血して血中 $\mathrm{C} 3 \mathrm{a}$, $\mathrm{C} 5 \mathrm{a}$, thromboxan $\mathrm{B}_{2}\left(\mathrm{TxB}_{2}\right)$ platelet factor $4\left(\mathrm{PF}_{4}\right) \beta$-thromboglobulin $(\beta-\mathrm{TG})$, leukotrien $\mathrm{B}_{4}$ $\left(\mathrm{LTB}_{4}\right)$, 白血球数 (IUBC), 血小板数 (PLt) を測定し, PMMA, 再生 cellulose を用いた 6 名と比較検討した。

WBC は 3 種の膜いずれでも減少していたが, 再生 celluloseで有意な減少がみられた。PLtは特に差はみられなかっ た. C3a，C5a はともに 15〜30 分で再生 cellulose 使用時に 著明な上昇が認められ, PMMA では上昇は認められず, Hemophan では軽度上昇した。 $\beta-\mathrm{TG}, \mathrm{PF}_{4}$ はともに血小板 $\alpha$ 顆粒中に存在する血小板特異蛋白である。PMMAにおい て両者は有意に上昇し, 再生 cellultne と Hemophan では 上昇はわずかであった。 $\mathrm{TXB}_{2}$ は $\mathrm{TXA}_{2}$ の代謝産物で Hemophan では上昇しなかったが PMMA と再生 cellulose の両者では顕著な上昇がみられた。 $\mathrm{LTB}_{4}$ は 3 者の間に有意 な差はなかったが PMMA と再生 cellulose は Hemophan よりわずかに上昇していた。 新しく開発された modified cellulose は補体活性化, 血小板活性化のいずれの面に扔いても 優れた生体適合性を有する膜であると考えられる。

\section{血液透析中のロイコトリエンの変動について}

金森 直明 宍戸 寛治 中島 豊 衣笠えり子 関口 孝 中山 文義 秋沢忠男 北岡 建樹

越川 昭三

昭和大学藤が丘病院内科

アラキドン酸からリポキシゲネーゼで代謝されるロイコト リエン $(\mathrm{LT})$ は，血液・膜間相互作用の指標として重要な意 
義を持つと推定されるが，これまで血液透析 (HD) 中の LT の変化に関する報告はほとんどない. 今回 $\mathrm{LTB}_{4}, \mathrm{LT} \mathrm{C}_{4} / \mathrm{D}_{4}$ complex を RI 法で測定し，腎不全，HDの影響を検討した。 早期空腹時の血漿 LT 濃度は正常人，定期透析患者で差は みられなかった。 HD 中 LT は前值に比し動脈側, 静脈側と も有意の上昇を認めたが, 動静脈の比較では, 静脈側に高值 の傾向を認めた。補体活性化の強い再生セルロース膜と補体 活性化の弱い PMMA 膜における動脈側 LT 濃度の経時的 変化の比較では, 前值に対し再生セルロース膜で PMMAに 比して有意に高い上昇率を示した.一方, 通常の再生セルロー ス膜と補体活性化の弱い新セルロース膜で動脈側 LT 濃度 の経時的変化を比較すると, LT 上昇率は新セルロース膜で 軽度であった。ヘパリン, FUT-175 で LT 濃度に対する抗 凝固剂の影響を比較検討したが，両抗凝固剤間に LT 上昇率 に有意差は認められなかった。

以上の成績から，早期空腹時 LT 濃度は腎不全，HD 群で 正常域にあるが HD 中経時的に LT 濃度は上昇する。その 程度は補体活性化作用の弱い PMMA 膜や新セルロース膜 使用群に比して活性化作用の強い再生セルロース膜使用群で 高度であったことから，LT 上昇に補体活性化の関与する可 能性が示唆された。LT は HDの白血球系への影響を示す指 標として有用と思われた。

\section{透析患者におけるエチレンオキサイド（EO）皮膚アレ ルギーの発現性について}

桜井 信也 伊藤 家勝 永吉 武彦 岩崎 秀明 嶋田 俊恒 鹿島 孝*1 大島 郁也 ${ }^{* 2}$ 小高 通夫*2 千葉社会保険病院 三愛記念クリニック*1 千葉大学第 2 外科 $* 2$

透析患者の皮膚アレルギーテストの結果が透析の前後で異 なる場合があり，その原因の一端を解明しようと試みた。

方法・結果: 安定期の長期透析症例中, 末梢血好酸球率 $15 \%$ 以上の 15 例に non-EO 透析器材を使用して好酸球率減 少の有無を確認した。 14 例に好酸球率の減少をみた. RAST 法 (鹿島らの方法) では 6 例がEO抗体陽性であった. 透析前 と後にプリックテストにて $\mathrm{EO}$ 皮膚アレルギーを観察した. 透析前皮膚テストは陽性者 9 , 疑陽性者 1 , 陰性 5 名であっ た。透析後皮膚テストは陽性者 5 , 疑陽性者 3 , 陰性者 7 名 であった. 透析前と後の末佾白血球を採取し, in vitroにて 直接ヒスタミン遊離試験を施行した。透析前採取した場合, $\mathrm{EO}$ 添加により, 皮膚テスト陽性の 10 名, 陰性の 3 名, 計 13 名に特異的ヒスタミン遊離が認められた。2例はヒスタミン 遊離は計測されず，皮膚テスト，RAST 法ともに陰性であっ た。透析後採取した場合，6例にヒスタミン遊離が認められ
た. 透析後採取したリンパ球を透析前採取した白血球に加え た時ヒスタミン遊離量は影響を受けなかった。末梢血好塩基 球数は透析後平均 $12 \%$ 減少した。

透析患者の 1 型皮膚アレルギー反応は透析後では減弱する 傾向がある. その機序はリンパ球組成の変化によるサプレッ ション, 抗原過剩, 好塩基球数の減少等によるものではない. in vitro で再現性があり, 液性因子の直接関与はないと思わ れる、1 型アレルギー反応のエフェクター細胞の 1 つである 好塩基球が透析中に何らかの修飾を受けて質的に変化するこ とが皮膚テスト減弱の原因の一端を成していると考えられ る.

\section{血液透析患者の血中 limulus test 陽性物質について（第 2 報）}

青山 悦子 山本 光祥 野澤 章夫 中村 正夫 金沢司 ${ }^{* 1}$ 小嶋 茂利 ${ }^{* 1}$ 大和田 滋 ${ }^{* 1}$ 石田 尚志 ${ }^{* 1}$ 聖マリアンナ医科大学臨床検查医学 同腎センター*1

エンドトキシン (Et) 以外の limulus test 陽性物質が再生セ ルロース膜由来による HD 患者血中に存在することを報告 した。 今回は HD 患者血中の本物質の蓄積性について検討し た。

慢性腎不全で新たに HD 施行された症例の HD 前後を経 時的に採血し，PRP を得た。カブトガニの凝固系のC因子， G因子を含む測定試薬 Toxicolor (生化学工業)，G因子を除 去した Et により特異的なEndospecy（生化学工業）を用い， 患者 PRP 中の limulus test 陽性物質と Et 量を測定した.

Et は経過中著明な異常值を示さなかった。一方 limulus test 陽性物質は HD 導入時から 20 回目までの蓄積には個人 差がみられたが，40 回目には全例に顕著な蓄積傾向を認め た。本物質の蓄積量と尿量との間に相関はみられなかった。 再生セルロース膜による HD を重㸚る毎に limulus test 陽 性物質が患者血中に蓄積される傾向がある。本物質は原料由 来でG因子を活性化することによって limulus test 陽性とす るため, $\beta$-glucan 様物質と推定されている。しかし, 蓄積傾 向がみられたことにより尿中へそのままクリアランスされる ことは考えにくい，本物質は体内で何らかの代謝を受け，そ の代謝の違いが蓄積の個人差となって現われたとも考えられ る.さらに本物質が体内に長期間蓄積することにより生体に 何らかの影響を及ぼす可能性を考慮しなければならない。本 物質が pyrogen としては検出されないので，C因子，G因子 を含む limulus chromogenic test と Et により特異的に反応 する測定系を用いて，医療器具のチェックを行うことが必要 である。

\section{討 論}

秋沢（昭和大学藤が丘病院） 佐々木先生にお伺いしたい のですが, modified cellulose でトロンボゲネスティも
リューコサイトの activation の方もなくなった。 それは表面 の材質によってそういうことが起こったと思われるのです 
が，どういう機序でそういうふうになったと考えたらよろし いのでしょうか.

佐々木 そこのところは私どもはっきり検討していないの ですが，血小板の中に凝集，放出，粘着という3つの機序が 㗢いている。実際に血小板の数としては変化がないというこ とから，3つの段階すべてが進んでいるのではなく，どこか でとまっているのではないかというふうに考えるのですが， そこがどうしてそこまで進まないのかということは，はっき りわからない.これから検討したいと思います。

秋沢 modified cellulose というのは表面の $\mathrm{OH}$ 基をつぶ して, $\mathrm{OH}$ が補体の活性基ですから補体の活性化が少なくな るというのはある程度わかるのです。では，その補体の活性 基をなくしたからトロンボゲネスティも再生する恐れも若干 よくなったというのは，なかなかその辺が難しいところでは ないかと思います。

表面性状としてはかえってカチオニックになっているとす ると, トロンボゲネスティは悪くなるのではないかというよ うな懸念もあると思うのですが，またその辺わかりましたら 教えて下さい.

佐々木 わかりました。どうもありがとうございます。

山上 この 3 題はメンブレンと血液成分, とくにコンプリ メントという，そういう生体側とのインターラクションの問 題を論じられていると思うのですが. 先生のところは血小板 機能ということでメンブレンを変えて評価されているわけで すね. 特に血小板機能をやります場合に血小板凝集能でもそ うですが，いろいろなパラメーターの問題です。たとえばへ マトクリットの問題. それから透析を施行しているときのへ パリン量の問題. ヘパリン自体が血小板機能に対していろい ろな作用を持っているということがあります。あるいは血小 板数というような問題です。その辺についてはかなりマッチ されて，検討されておりますか.

前島 山上先生がおつしゃつたように血液学的パラメータ を調べるには，さまざまなそういう諸因子をなるべく出して 同じにそろえたいものですが，一応，患者さんの血小板数は 大体 15 万〜 30 万までで数的にはそれほど問題になる範囲で はないと思います。

ダイアライザーの方もなるべく膜面積も同じで透析液量も 同じようにしてやりました。最終的なへマトクリットで血小 坂数の補正はしておりませんが, 血液学的パラメー夕を調心゙ るにはそういうさまざまな諸因子とへパリンの影響もありま すし，生体側を通すダイアライザーにもありまして，なかな か困難でありましたが，一応今回の結果はこういう結果に なったということです。

山上 たとえばへパリン自体の量に差があるとかいうこと はないわけですね.

前島 ヘパリンは全員がはっきり全部同じとは限りません が，大体同じ量だったと思います。へパリンですが，私たち も一応, 透析療法学会ではありませんが, 日本腎臓学会の方 で血小板凝集能についていろいろ報告して抢ります。その際 にへパリンの影響というものがどういうものなのか.一応,
何例か無へパリン透析を行いまして, 症例によってはへパリ ンによって血小板減少症と言いますかそういう方もあります けれども, 今回の症例には当然そういう人は入れておりませ ん、へパリンの影響はこれまでの感じではあまりなかったと いう感じがいたします。

山上 メンブレントと血小板機能というようなことでござ いますけれども。稲永先生のご演題でございますけれども， 血小板だけでなく，リンパ球のサブセットもいろいろな膜の 間に差がある。一言で言いましてどうなのでしょうか. 合成 高分子膜と再生セルロースのどちらがいいというふうにお考 えになるのでしょうか.

稲永 補体の活性化から見ますと, $\mathrm{C}_{3 \mathrm{a}}$ より PMMA 膜の 方が上昇が少ないので合成膜の方がいいと思います。ただ， リンパ球で OKT4, OKT8 の比を見ますと 15 分後は多少 PMMA 膜の方が少し上昇しているみたいですが，これが長 い目でみたとき……透析後半は上がっていますが, 次の透析 のときにはまた戻っているという状態で, 長い目で見た場合 にリンパ球のサブセットから見るとどちらがいいということ は，いまの時点では断言できないと思います。

補体の活性化の面だけを見れば合成膜の方がいいような印 象は受けるのです.ただ,これが 5 年 10 年と長期になった場 合にどうかということは，また別の問題だろうと思います。

山上 直接関係しているかどうかは別としまして, 佐々木 先生の発表の中で PMMA でトロンボキサン $\mathrm{B}_{2}$ が産生され るというような事実に対してはどういうふうなコメントをお 持ちですか. 直接にリンパ球サブセットに作用する云々は別 としまして，そういう現象はありますね。

稲永 私その辺, 詳しいことは検索して扔りませんが, 1 回の透析で変化が少ない方が生体に対してはべターだと思い ますので, 変化は少ない方がいいのではないかと思います。 詳しいことはわかりませんが……

金森 佐々木先生, ロイコトリエン B4 は PMMA 膜と再 生セルロース膜では差があったでしょうか。

佐々木 有意差は見られておりません。ただ，私たち静脈 側から採血しましたので，抄録を読ませていただきました先 生方は動脈側ですので, そこのところ,こちらも動脈側をこ れから検討いたしたいと思っております。

山上 メンブレンの生体適合性を評価するのにロイコトリ エンが 1 つのパラメーターになるのではないか. 実際，ロイ コトリエン B4 などというのは白血球輸送能というようなも のに対して，かなり影響を持っているということでございま しょう。佐々木先生何かコメントございませんか.

佐々木 1 つ据きしたいのですが，ロイコトリエン B4 ですが補体系に関与するとすればどのような形で関与すると お考えでしょうか。

金森 たとえば $\mathrm{C}_{5 \mathrm{a}}$ が活性化されて生体内で白血球凝集粘 着に関与して, それが生体のいろいろな組織で刺激となって ロイコトリエンが生体内でも放出されるのではないかと想像 しています。 
佐々木 そうしますと，そのときにほかのヒスタミン系と かそういうものも上がっているとお考えでしょうか.

金森 今回，そちらの方は測っていませんのでわかりませ h.

山上いかがでございましょうか. 非常に新しいパラメー 夕と言いますか. 従来まで使われていなかったパラメータに なり得る可能性というのは随分あると思うわけです。

高橋（信楽園病院）透析中の血液ガスの変動の方とは何 か関係ございませんでしょうか.

金森 実はロイコトリエンの経時的な上昇について，多少 検討は加えたのですが，上昇する群とピークがある群とそこ にバラツキがあったので，ガスの方との相関もはっきりした ことはわかりませんでした。

長沼（東京女子医大腎藏病院総合医療センター） 前の発 表でも議論されていますように, 血小板とか白血球の変動と の相関とか見ていますと, やはり少しバラツキがあるようで すが，同じ膜でも血小板とか白血球の相関性があったでしょ うか。

金森 その相関についてはっきりしたことは, 今後しっか りデータをまとめて報告したいと思いますけれども，現時点 では先ほど言ったように確かに白血球減少する 15 分でロイ コトリエンがピークを見せる分とかありましたが，その辺は まだはっきりしたことは言えません。

猿渡 桜井先生のご発表は透析の滅菌に使われますエチレ ンオキサイドがいろいろな形でアレルギー反応に関与してい るのではないかというような発表だと思いますが, いかがで ございましょうか.これにご質問，ご追加ございましたらお 願いします。

坂下（衆済会増子病院）私たちも 4 年ほど前にずっと EOG をやって扔りまして, 全部の器材の EOG をやってみま したけれども，やはりある症例では好酸球が下がらなかった というケースがあるわけです，好酸球が下がらない症例につ いての好酸球増多の機序について何か教えていただきたいと 思います。

桜井 穿刺針まですべて変えるとみんな下がってまいりま す。それで最初の症例にはアレルギーを有する患者が実は 3 名含まれていまして，6例についてはすべてを EOG を用い ない器材に変えたのですが，その中の 1 例は喘息がございま して，この方は $15 \%$ までは下がってきたのですが，最終的に は $11 \%$ 前後でとどまっていて, 喘息は発作と関係があるよう に思われます。

変えるとやはり下がってくる，あるいはゆっくりですが下 がってくるように思います。 1 年半ぐらい追っかけてきてい ますと，大体 $10 \%$ 未満にみんな下がってくるように思いま す.

山上 キプロハン透析膜から青山先生のご発表のような $\beta$ ーグルカンライクサブスタンスというものが出てきて透析期 間の間にそれが体内に蓄積するという報告でございます．私
どももこういうふうなことを 4 年ほど前からやっております けれども,やはり最近では HPLCを使いましてピアソンあた りのトレースをやりましたところ, やはり $\beta$-グルカンの可能 性と云うことが判ったことがあります。

坂下（衆済会増子病院）私どもも limulus test をやって おりますが，いまの透析初回からの経日的に行った透析前值 での蓄積ですが，あそこに書いてありましたダイアライザー というのはウエットタイプのダイアライザーと思いますけれ ども，ドライタイプのダイアライザーでやりますと，1回の 透析で測定の検量線の $50 \mathrm{pg}$ をかなり超える範囲. 換算で言 いますと $300 \mathrm{pg}$ をかなり超える範囲で 1 回でやりまして,そ れがずっと持続するというデータを得ております。

もう 1 つは,一番最初に出された患者ごとのレベルですが, 先ほど言いましたように検量線が直線性を示すのは大体 50 pg で, 血清ですと 6 倍して $300 \mathrm{pg}$ なわけですけれども, そ れ以上の高さについてどのように測定したかということと, 下の群と上の群とありましたが，それがダイアライザーのド ライタイプとウエットタイプで違いがあったかどうか教えて いただきたいと思います。

青山 最初のご質問ですけれども, 検量線を振り切れた場 合には途中で希釈いたしまして, 約 200 倍希釈から，ものに よっては 2,000 倍希釈近くまで前処理をし終わったあとにア ルカリを加えて中和をしたあとに滅菌蒸留水を加え, 希釈し てもう一度測定を行いました。

2 番目のご質問ですが，一応あれはすべてウエットタイプ で行っていると思いますが，やはり上の方で limulus test 陽 性物質の蓄積量が多いものは, HD の回数をかなり行ってい る症例でした。

坂下 蓄積性についてはわれわれも調べたのですが，あま り変化がありませんでした，それは特にドライタイプですが ウエットタイプについてはあまりやっていないものですか ら，透析歴との関係をまた調べていただきたいと思います。

山上 どうもありがとうございました。ここで少しコメン トをさせていただきますと,この $\beta$-グルカンライクサブスタ ンスですが，1つはやはり蓄積という問題と，もう1つはデ グラデーションの問題です.どういう形で代謝されていくか. これも抗腫瘍多糖類, 特にPSK ークレスチンなどが同じよ うな挙動をとるということで，クレスチンをマーカーにしま して代謝を追いますと, 腎不全の患者さんではかなり落ちて いるということが，確認されております。

それともう 1 つは, こういう $\beta$-グルカンと limulus 陽性物 質はどこからきているというふうに怙考えでしょうか。クプ ロハン膜ではこういうものが出てきますと, どういうことで 出てくるというふうに招考えでしょうか.

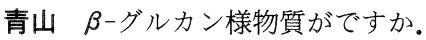

山上そうですね.

青山 クプロファン膜から溶出されると考えているという 答えでよろしいでしょうか.

山上 いままでの報告では一応コットンリンター, 素材由 来ということを言われているのですが……どうもありがとう 


\section{ございました。}

総括いたしますと，ダイアライザーの生体適合性という問 題を考えますと，体外循環，あるいはダイアライザーを使う ということが，まず非生理的行為でごずいます。生体適合性 に反することをやっております。しかし腎不全という病態を 改善するためにはこういう非生体適合的な行為をやらなけれ
ばならない以上，それはやはりリスクの少ないメンブレン， あるいはフィルター，あるいは新しい測定というものを十分 に検討した上で，やはり新しい方式というもの，あるいは改 良点というものを追求していくという姿勢が必要ではないか ということでございます。

\section{湢胆汁分泌促進㓮}

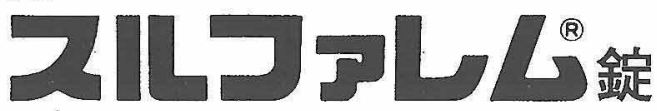

アネトールトリチオン $12.5 \mathrm{mg} /$ 錠 含有

〔適 応 症〕下記疾患における利胆

胆道（胆管・胆のう）系疾患及び胆 汁うっ滞を伴う肝疾患

[用法用量]アネトールトリチオンとして通常成 人 1 回25mgを 1 日 3 回経口投与 年令・症状により適宜增減

[楽理作用] (1) 催胆作用

(2) 肝機能倵活作用（血中 G S H 值上 昇 /色菜排泄能促進 / 尿素合成能 促進 / 肝コレステロール量調整)

薬理作用の詳細及び使用上の注意については製品 添付文書をご参照下さい。

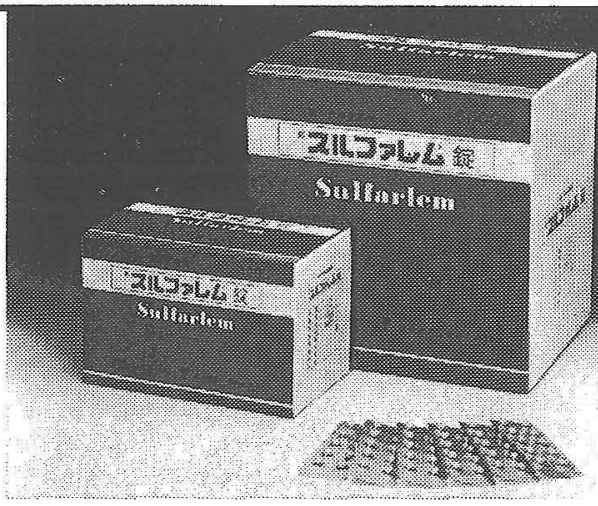

[包荘]

1,200 錠 6,000 錠

(PTP） 10 錠 $\times 12010$ 錠 $\times 600$

○同一成分製郕にスルファレム丸(12.5mg/丸)があります。

規制区分：劇 薬

薬価基準収戴品

製造東菱楽品工業株式会社 東京都千代田区有楽町1-10-1

提携 う テ マ 社 (フランス) 賠 売 $\overrightarrow{\text { 元 }}$

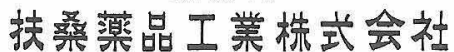
大阪市東区道修町 2 丁目 50 雷地 